\title{
SUSCETIBILIDADE A ESCORREGAMENTOS E RISCO DE QUEDA DE BLOCOS NO GEOSSÍTIO COLINA DO HORTO, JUAZEIRO DO NORTE/CE
}

\author{
Sinara Gomes de Sousa ${ }^{1}$ \\ Maria Luísa Gomes da Silva ${ }^{2}$ \\ Thaís Mara Souza Pereira ${ }^{3}$ \\ Manuella Pontes Barbosa ${ }^{4}$ \\ Fabrizio de Luiz Rosito Listo $^{5}$
}

\begin{abstract}
Resumo: Neste trabalho buscou-se identificar áreas suscetíveis a ocorrência de movimentos de massa, enfatizando as tipologias de escorregamentos translacionais rasos e queda de blocos no perímetro de abrangência do Geossítio Colina do Horto, município de Juazeiro do Norte, estado do Ceará. Para tal proposta, foi gerado um mapa de suscetibilidade a partir do modelo matemático SHALSTAB (Shallow Landsliding Stability Model), considerado um modelo de previsão determinístico, além de atividades em campo para identificar e registrar pontos de ocorrência a quedas de blocos. O modelo previu uma suscetibilidade média a baixa para a ocorrência de escorregamentos translacionais devido a incipiência do manto de intemperismo. Quanto às quedas de blocos, constatou-se que a sua ocorrência se dá por meio de uma convergência de fatores, tais como, declividades em torno de $75 \%$; predominância do intemperismo físico e biológico na abertura de fraturas nos pacotes rochosos; ação antrópica por meio de cortes nos taludes para construções de prédios residenciais, comerciais e vias de acesso. Este trabalho poderá colaborar no conhecimento dos processos exógenos do Geossítio Colina do Horto, subsidiando trabalhos de monitoramento aos possíveis desastres naturais na área.
\end{abstract}

Palavras-chave: Movimentos de massa; suscetibilidade; SHALSTAB.

\section{SUSCEPTIBILITY TO LANDSLIDES AND RISK OF FALLING BLOCKS IN THE GEOSSÍTIO COLINA DO HORTO, JUAZEIRO DO NORTE/CE}

Abstract: This work aimed to identify areas susceptible to the occurrence of mass movements, emphasizing the typologies of shallow landslides and rockfall in the perimeter of the Geossítio Colina do Horto, in the municipality of Juazeiro do Norte, in the state of Ceará. For this proposal, a susceptibility map was generated from the mathematical model SHALSTAB (Shallow Landsliding Stability Model), considered

\footnotetext{
${ }^{1}$ Universidade Federal de Pernambuco. sinarageogomes@live.com.

${ }^{2}$ Universidade Federal de Pernambuco. luisags19@gmail.com.

${ }^{3}$ Universidade Federal de Pernambuco. thaismara estrela@ hotmail.com.

${ }^{4}$ Universidade Federal de Pernambuco. manuella.pontes@live.com.

${ }^{5}$ Professor da Universidade Federal de Pernambuco (UFPE). fabrizio.listo@ufpe.br.
}

Estudos Geográficos, $\quad$ Rio Claro, 16(2): $193-212, \quad$ jul./dez. $\quad 2018 \quad$ (ISSN $1678-698 X)$

http://www.periodicos.rc.biblioteca.unesp.br/index.php/estgeo 
the deterministic prediction model, besides field activities to identify and record points of occurrence of rock fall. The model predicted a medium to low susceptibility for the occurrence of translational landslides due to incipience of the weathering mantle. Regarding the rockfall, it was verified that happens through factors such as: slope around 75\%; predominance of physical and biological weathering in the opening of fractures in the rocky package; anthropic action through cuts on the slope for residential, commercial, and highways constructions. This paper can collaborate in the knowledge of the exogenous processes of the Geossítio Colina do Horto, subsidizing works of monitoring the possible natural disasters in the area.

Keywords: Mass movement; susceptibility; SHALSTAB.

\section{INTRODUÇÃO}

A geoconservação é o cerne de discussão das ciências em geral, especialmente aquelas que objetivam proteger e valorizar o patrimônio histórico, geológico e turístico. Desta forma, os geossítios surgem como ferramenta de gestão territorial, bem como ambiental, contribuindo para a proteção e a conservação de áreas de grande geodiversidade, que apresentam valiosa beleza cênica, geológica e forte atração turística (BORBA, 2013).

Neste contexto, no território brasileiro existem alguns geossítios, dentre eles, o Geossítio Colina do Horto, localizado no município de Juazeiro do Norte, sul do Ceará. O Geossítio em questão faz parte do Geopark Araripe, cuja função é conservar o patrimônio geológico, paleontológico, geomorfológico e a biodiversidade da área (GEOPARK ARARIPE, 2011).

Existe, na área, uma grande movimentação turística anual, de modo que, os aspectos históricos, geológicos e geomorfológicos denotam a beleza cênica da paisagem do Geossítio. É também conhecido como Geossítio Granito por possuir uma área significativa de formações geológicas do período Pré-Cambriano, sendo considerada uma das formações mais antigas da área do Geopark Araripe, muito relevante para o desenvolvimento de pesquisas científicas (ALVES, 2010).

O Geossítio Colina do Horto possui um embasamento geológico bastante suscetível a movimentos de massa, sobretudo as quedas de blocos, ressaltando-se ainda que na área adjacente ao Geossítio existem construções urbanas em áreas muito declivosas. As quedas de blocos são um tipo de processo morfodinâmico caracterizado por um movimento rápido de blocos e/ou lascas de rocha, que se rompem pela ação da gravidade, sem a presença de uma superfície de deslizamento, na forma de queda livre. É um processo de difícil previsão, não possuindo planos de deslocamento, que atinge velocidades muito altas, e o volume do material pode variar ente lascas, placas ou blocos (GERSCOVICH, 2012). Deste modo, as encostas são, por natureza, ambientes mais propícios a ocorrência de erosão e de movimentos gravitacionais de massa (GUERRA, 2011).

De acordo com Pinotti e Carneiro (2013), as causas das quedas de blocos podem ser variadas e, normalmente, estão associadas à perda da sustentação dos matacões por meio da ação erosiva da água, da variação térmica do maciço rochoso, de vibrações e de alívios de tensão. Nesta perspectiva, os mapeamentos de suscetibilidade e de risco são de extrema relevância para o planejamento urbano, e para a prevenção de desastres naturais de grande dimensão; os quais vêm ganhando grande força diante da iminência do surgimento inadequado de cidades

Estudos Geográficos, Rio Claro, 16(2): 193-212, jul./dez. $2018 \quad$ (ISSN 1678-698X) http://www.periodicos.rc.biblioteca.unesp.br/index.php/estgeo 
em todo o mundo, com destaque para o Brasil (FERNANDES, 2001; SBROGLIA et al., 2017).

Nesse contexto, modelos matemáticos aliados às técnicas cartográficas foram desenvolvidos para subsidiar o monitoramento e uma possível gestão de espaços suscetíveis a movimentos de massa. Para auxiliar no monitoramento e na previsão dos desastres naturais causados por escorregamentos translacionais rasos, foi desenvolvido o modelo matemático SHALSTAB (Shallow Landsliding Stability Model) que vem demonstrando resultados muito eficientes em suas aplicações (MONTGOMERY e DIETRICH, 1994).

O SHALSTAB é um modelo matemático desenvolvido por pesquisadores norte-americanos, Montgomery e Dietrich (1994), e sua aplicação é bastante difundida no âmbito geomorfológico. De acordo com LISTO (2016) e Sbroglia et al., (2017), o SHALSTAB consiste em um modelo matemático determinístico que faz uso de dados espacializados, para calcular o grau de suscetibilidade a escorregamentos translacionais rasos em cada pixel de um grid, por meio da razão entre a quantidade de precipitação (chuva crítica necessária para a deflagração de escorregamentos) e a transmissividade do solo.

No Brasil, a modelagem do SHALSTAB vem sendo muito aplicada, sobretudo pela recorrência de movimentos de massa, em especial, os escorregamentos. Apesar das pesquisas do modelo no país possuírem uma maior incidência e concentração nas regiões Sudeste e Sul, todas as regiões brasileiras estão sujeitas a ocorrência deste processo (BASTOS e PEULVAST, 2016). Entretanto, na região Nordeste, principalmente no semiárido brasileiro, as aplicações deste modelo ainda são incipientes. Diante deste cenário, o presente trabalho visa avaliar a suscetibilidade a duas tipologias de movimentos de massa, isto é, escorregamentos translacionais rasos, por meio da aplicação do modelo SHALSTAB, e de quedas de blocos, a partir de trabalhos de campo, no recorte escalar do Geossítio Colina do Horto (Juazeiro do Norte - Ceará).

\section{ÁREA DE ESTUDO}

O Geossítio Colina do Horto faz parte da rede de geossítios que compõem o Geopark Araripe, e situa-se no município de Juazeiro do Norte, sul do Ceará, Nordeste do Brasil, limitando-se a norte com os municípios de Caririaçu, a oeste com Crato, a sul com Barbalha e a leste com Missão Velha (Figura 1). A extensão territorial do município corresponde a 248,558 km² com uma altitude média de $377 \mathrm{~m}$ (IPECE, 2017).

Estudos Geográficos, Rio Claro, 16(2): 193-212, jul./dez. $2018 \quad$ (ISSN 1678-698X) http://www.periodicos.rc.biblioteca.unesp.br/index.php/estgeo 


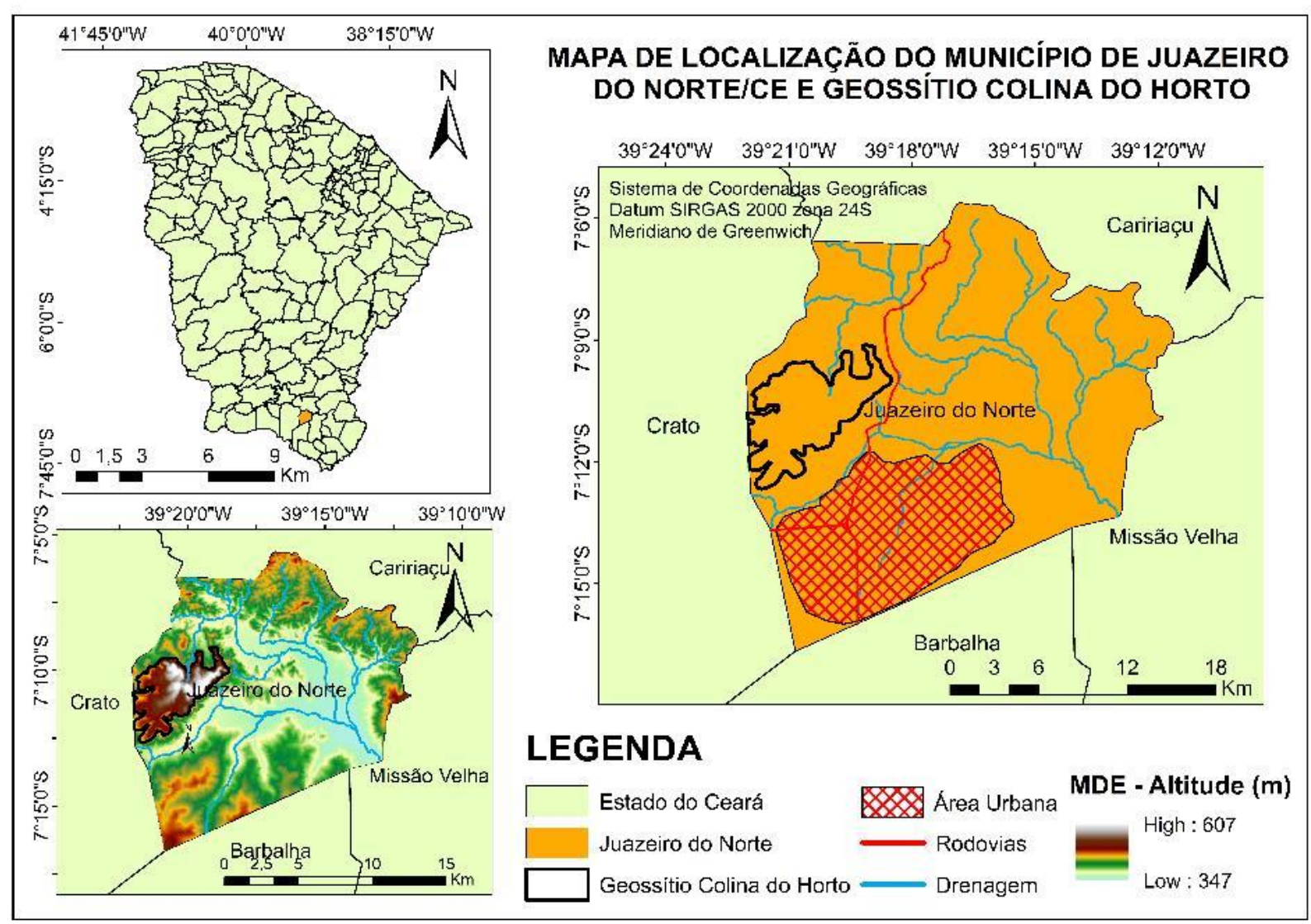

Figura 1 - Localização da área de estudo.

A área situa-se, geomorfologicamente, na Bacia Sedimentar do Araripe, a qual está dividida em duas feições, a Chapada do Araripe e o Vale do Cariri (ASSINE, 1990). O Vale do Cariri faz parte da sub-bacia do Cariri, e possui formação geológica distinta da área da Chapada do Araripe (notadamente sedimentar), estando associada as unidades das sequências rifte, pré-rifte e paleozoica. $O$ município está associado a sequência rifte e a formação Abaiara (ASSINE, 1990).

A sub-bacia do Cariri apresenta estrutura formada por horsts e grábens, os quais são definidos por falhas principalmente na direção NE. Ainda segundo Assine (1990), o gráben Crato-Juazeiro possui estrutura rúptil, aliada principalmente a eventos tectônicos modificadores, que podem estar relacionados a um segundo evento da fase rifte. Os processos erosivos locais foram responsáveis pela erosão dos blocos altos e pediplanação do relevo restante.

O clima da região segue a tendência do quadro climático do Nordeste do Brasil (NEB), que é marcado por uma estação chuvosa, irregular e por uma estação seca, que pode ser curta ou prolongada a depender da área (LIMA, 2015). Dessa forma, os fenômenos sinóticos que atuam no NEB com maior intensidade de acordo com a época do ano, são a Zona de Convergência Intertropical (ZCIT), que obtém sua posição mais ao sul da linha do equador entre os meses de fevereiro a abril e representa uma área de baixa pressão, responsável pela formação de nuvens principalmente na parte Norte da região Nordeste do Brasil.

A ZCIT e a formação de Vórtices Ciclônicos de Altos Níveis (VCAN) contribuem para que o período chuvoso na região seja condensado em poucos meses, sucedendo-se em irregularidades pluviométricas no tempo e no espaço. Os VCANs se formam no Oceano Atlântico e adentram o Brasil na direção leste-oeste,

Estudos Geográficos, Rio Claro, 16(2): $\quad 193-212, \quad$ jul./dez. $2018 \quad$ (ISSN $\quad$ 1678-698X) http://www.periodicos.rc.biblioteca.unesp.br/index.php/estgeo 
possuem maior ação entre os meses de janeiro e fevereiro e as frentes frias atuam, principalmente, entre os meses de novembro e janeiro. As linhas de instabilidade que estão mais presentes nos meses de fevereiro e março, e os complexos convectivos de meso-escala (CCMs), que são responsáveis pelas chuvas fortes e de curta duração, atuam no hemisfério sul nos meses que correspondem ao verão (FERREIRA; MELO, 2005).

Silva et al. (2010), em um estudo climatológico para o município de Juazeiro do Norte, desde o ano de 1979 até o ano de 2008, verificou que o trimestre mais chuvoso para o período supracitado corresponde aos meses de janeiro, fevereiro e março, com maiores médias mensais para o mês de março $(925 \mathrm{~mm})$. Já o trimestre mais seco equivale aos meses de agosto (principalmente), setembro e outubro; sendo a precipitação anual do município equivalente a $256 \mathrm{~mm}$ para este período. Em linhas gerais, o município é influenciado, climatologicamente, pela Chapada do Araripe, condicionando uma elevada taxa de precipitação anual, o que também é possível verificar para os municípios vizinhos, na qual sua disposição orográfica favorece a ocorrência de um mesoclima subúmido (LIMA, 2015).

Pedologicamente, a área é constituída, predominantemente, por Latossolos, mais desenvolvidos, e por Neossolos, menos desenvolvidos; sendo o Neossolo Litólico Eutrófico a classe predominante da Colina do Horto, associado a presença de afloramentos rochosos. A partir do levantamento realizado pela FUNCEME (Fundação Cearense de Meteorologia e Recursos Hídricos) (2012), estão presentes as seguintes classes de solos: Neossolo Litólico Eutrófico, Neossolo Flúvico Eutrófico, Latossolo Vermelho-Amarelo, Argissolo Vermelho-Amarelo Eutrófico e, em menor representatividade, o Argissolo Vermelho-Amarelo Distrófico e o Neossolo Quartzarênico Órtico. A vegetação que se desenvolve nesse ambiente é do tipo Caatinga Arbustiva-arbórea, caracterizando-se como um reflexo das interações litológicas, pedológicas e geomorfológicas (FUNCEME, 2006).

\section{MATERIAIS E MÉTODOS}

\section{MAPEAMENTO GEOMORFOLÓGICO}

O mapeamento geomorfológico foi produzido na escala de 1:100.000 no software ArcGis 10.3, a partir da análise do MDT (Modelo Digital do Terreno) imagem raster adquirida no projeto TOPODATA do Instituto Nacional de Pesquisas Espaciais-INPE, cena 07S405ZN -, imagens de satélite disponibilizadas pelo software Google Earth Pró, e perfis topográficos traçados por meio das ferramentas "Interpolate Line" e "Profile Graph" (ArcGis 10.3). A compartimentação e a delimitação das unidades se deu a partir da criação de camadas em polígono no formato shapefile e, posteriormente, a vetorização. Os procedimentos técnicos utilizados para este mapeamento seguiram os critérios estabelecidos pelo Instituto Brasileiro de Geografia e Estatística - IBGE (2009), e a classificação foi adaptada de Carvalho Neta (2016).

O mapeamento está dividido em duas unidades morfoestruturais e delas subdividiram-se unidades menores que representam as feições morfoesculturais. Entende-se por morfoestrutura as categorias que respondem pelas formas maiores do relevo, tratadas em escala regional como planaltos bombeados em estruturas dobradas, bacias sedimentares ou cinturões orogenéticos modernos (CORRÊA et al., 2010). Já as morfoesculturas são consideradas áreas menores que foram

Estudos Geográficos, Rio Claro, 16(2): 193-212, jul./dez. $2018 \quad$ (ISSN 1678-698X) http://www.periodicos.rc.biblioteca.unesp.br/index.php/estgeo 
esculpidas por processos exógenos, como os elementos climáticos, e a drenagem (OLIVEIRA et al., 2007).

\section{CENÁRIO DE SUSCETIBILIDADE A ESCORREGAMENTOS - MODELO SHALSTAB}

O SHALSTAB necessita de parâmetros topográficos e geotécnicos (valores físicos do solo) para definir as áreas que apresentam maior ou menor suscetibilidade a escorregamentos rasos a partir da identificação do grau de instabilidade de cada setor da paisagem a ocorrência do processo (MONTGOMERY e DIETRICH, 1994; LISTO, 2016; SBLOGLIA et al., 2017).

Com o intuito de facilitar o seu uso e de tornar a sua execução mais rápida, foi utilizada na modelagem uma ferramenta desenvolvida por SBLOGLIA et al., 2017 por meio do ESRI's Model Builder, denominada Automatic SHALSTAB Analysis (ASA), que possui a função de automatizar os processos necessários para a obtenção do resultado. Tal ferramenta contém a rotina automatizada da equação matemática do modelo SHALSTAB (Eq. 01) cuja fórmula utilizada foi proposta por Montgomery e Dietrich (1994), sendo uma combinação de dois modelos, um modelo hidrológico que mede o grau de saturação do terreno e um modelo de estabilidade da encosta (MONTGOMERY E DIETRICH, 1994).

$$
\frac{q}{T}=\frac{b}{a} \cdot \operatorname{sen} \theta \cdot\left[\frac{c^{\prime}}{y_{w \cdot g \cdot z \cdot \cos ^{2} \theta \cdot \operatorname{tg} \varphi 1}}+\frac{y_{s}}{y_{w}} \cdot(1-\operatorname{tg} \theta)\right] \quad \text { (Equação 1) }
$$

Onde: q representa a intensidade da precipitação $(\mathrm{mm})$; T é a transmissividade do solo $\left(\mathrm{m}^{2} / \mathrm{dia}\right)$; a é a área de contribuição ou área drenada a montante $\left(\mathrm{m}^{2}\right)$; b o comprimento de contorno unitário que equivale à resolução espacial do grid (m); $\theta$ a declividade (graus). $\varphi$ é o ângulo de atrito efetivo entre os grãos de solo (graus); c' é o intercepto de coesão efetiva (kPa); g é a aceleração da gravidade $\left(\mathrm{m} / \mathrm{s}^{2}\right) ; \gamma_{s}$ é o peso específico do solo $\left(\mathrm{kg} / \mathrm{m}^{3}\right)$; e $\gamma_{w}$ é o peso específico da água $\left(\mathrm{kg} / \mathrm{m}^{3}\right)$ e z é a profundidade do solo $(\mathrm{m})$.

Os dados de entrada da ferramenta ASA utilizados foram o MDE (Modelo Digital de Elevação) em formato raster com resolução de $30 \mathrm{~m}$ de onde foram extraídos os parâmetros declividade e área de contribuição; a camada geotécnica (parâmetros físicos do solo) em formato vetorial e o "z.tif", que corresponde a camada com a profundidade do solo em formato matricial.

As camadas intermediárias são elaboradas automaticamente, a partir da ferramenta ASA, no formato matricial e não são salvas em ambiente digital. A camada matricial de declividade é extraída do MDE, a partir da opção Spatial Analyst Tools/Surface/Slope no ArcToolbox do software Arcgis, utilizando-se como parâmetro a variável declividade $(\theta)$, expressa em graus ou em percentual e reclassificada conforme a Figura 02.

Já a camada matricial de área de contribuição representa a fração $\frac{b}{a}$ da equação do SHALSTAB e consiste em uma superfície de acúmulo de fluxo a partir de suas direções, formando uma rede de drenagem. Esta camada, pode ser realizada por meio da técnica de oito direções, também sendo calculada por meio do ArcToolbox no software Arcgis, na opção Spatial Analyst Tools/Hidrology/Flow

Estudos Geográficos, Rio Claro, 16(2): 193-212, jul./dez. $2018 \quad$ (ISSN 1678-698X) http://www.periodicos.rc.biblioteca.unesp.br/index.php/estgeo 
Accumulation. Utilizando como dado de entrada a camada de 8 direções de fluxo, obtida a partir do valor de altitude das células vizinhas. Esta pode ser obtida em Spatial Analyst Tools/Hidrology/Flow Direction, tendo como dado de entrada o MDE.

Os parâmetros físicos do solo foram retirados da literatura a partir do trabalho de Melo e Bandeira (2014), (incluso) nos quais foram realizados ensaios de campo e de laboratório em áreas próximas ao Geossítio Colina do Horto, no próprio município de Juazeiro do Norte. Assim, os valores utilizados foram: Cs - coesão do solo: $0 \mathrm{~N} / \mathrm{m}^{2}$; $\mathrm{Cr}$ - coesão das raízes: $0 \mathrm{~N} / \mathrm{m}^{2}$; Rs - peso específico do solo: 1600 $\mathrm{kg} / \mathrm{m}^{3}$; F - ângulo de atrito: $35^{\circ}$ graus; $\mathrm{W}$ - carga proveniente da vegetação: $0 \mathrm{~N} / \mathrm{m}^{2}$ e Z - profundidade do solo em análise: 3 metros.

A partir dos dados gerados pela ferramenta ASA, utilizou-se a ferramenta Raster Calculator, para a realização automática do cálculo do SHALSTAB conforme a equação supracitada (já inserida). Posteriormente, foram produzidos dois arquivos em formato matricial, um correspondente ao resultado da modelagem em função de $\log (q / T)$ e outro representando o mesmo resultado, porém com a classificação do modelo (SBROGLIA et al., 2017). A classificação original possui sete classes, que representam a condição de instabilidade da área, sendo elas: incondicionalmente instável, incondicionalmente estável, e mais cinco classes intermediárias que variam entre $<3,1 \mathrm{e}>2,2$. Nesse artigo somente foram utilizadas 5 classes do modelo, desde a classe 3,1 - 2,8 até a classe de incondicionalmente estável (9.9). Essa escolha foi realizada, devido ao fato de não ter sido encontrado nos resultados do modelo nenhum grid correspondente as classes de incondicionalmente instável e a classe < 3,1 devido à previsão realizada pelo modelo para a ocorrência de escorregamentos na área.

\section{RISCO A QUEDA DE BLOCOS}

A partir dos mapeamentos confeccionados em gabinete, foram realizadas três atividades de campo (novembro de 2017, fevereiro e abril de 2018) tendo como objetivos a validação dos mapas, aquisição de imagens e análise dos processos morfodinâmicos, sobretudo as quedas de blocos. É importante ressaltar que a modelagem do SHALSTAB identificou apenas a suscetibilidade aos processos de escorregamentos, conforme as bases teórico-metodológicas do modelo, sendo as quedas de blocos identificadas exclusivamente por meio de trabalhos de campo.

Nesse sentido, o risco a queda de blocos foi avaliado em campo a partir da observação de matacões e de lascas de rochas depositados em setores da encosta, assim como a percepção de cicatrizes nos grandes pacotes rochosos que compõem a colina. Constatou-se também a presença de fraturas e pontos de fraqueza nas rochas, fato que acarreta (em conjunto com demais fatores) o desprendimento dos blocos e a sua queda. Os tipos de movimentos foram identificados com base nos tamanhos e na disposição dos blocos (processo de queda) e pelas cicatrizes (processo de desplacamento).

Estudos Geográficos, Rio Claro, 16(2): $\quad 193-212, \quad$ jul./dez. $2018 \quad$ (ISSN $\quad$ 1678-698X) 


\section{RESULTADOS E DISCUSSÕES}

\section{CARTA DE DECLIVIDADE, ÁREA DE CONTRIBUIÇÃO E MAPEAMENTO GEOMORFOLÓGICO}

O município encontra-se no contexto da Bacia Sedimentar do Araripe e apresenta uma configuração geomorfológica típica de regiões semiáridas destacando-se uma vasta planura composta por material sedimentar de tipologias diferenciadas, interrompida pela proeminência de uma intrusão granítica denominada de Colina do Horto com cotas atingindo os $600 \mathrm{~m}$. Com base no mapa de declividade (Figura 2), foi constatado que a maior parte da topografia do município se encontra dentro das classes ondulado, suave ondulado e plano, com exceção da ruptura de declividade abrupta ocasionada pela própria Colina do Horto, que apresenta um relevo bastante íngreme.

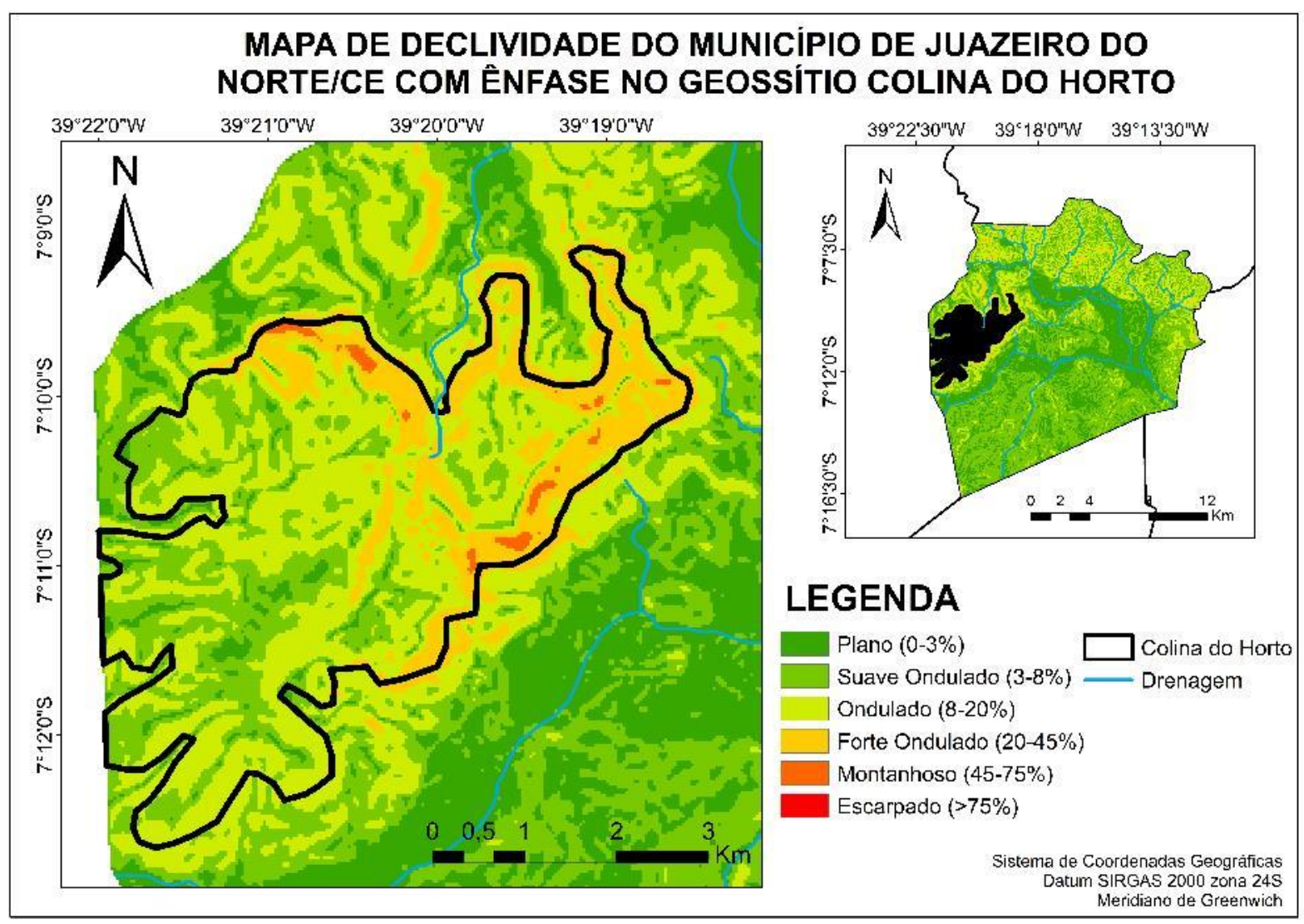

Figura 2 - Mapa de declividade do município de Juazeiro do Norte/CE.

Um dos atributos importantes para avaliar o grau de suscetibilidade a ocorrência de escorregamentos é a área de contribuição (Figura 3), pois permite identificar os setores de convergência de fluxos, e a partir disso mensurar os efeitos da saturação do manto de intemperismo decorrente da infiltração. Essa saturação é um dos fatores deflagradores dos escorregamentos, pois com a elevação do peso do material, o ângulo de repouso é rompido, facilitando a perda de apoio no contato do solo com a rocha, tornando a força de cisalhamento maior que a força de atrito.

Estudos Geográficos, Rio $\quad$ Claro, $\quad 16(2)$ : $\quad 193-212, \quad$ jul./dez. $2018 \quad$ (ISSN 1678 -698X) http://www.periodicos.rc.biblioteca.unesp.br/index.php/estgeo 


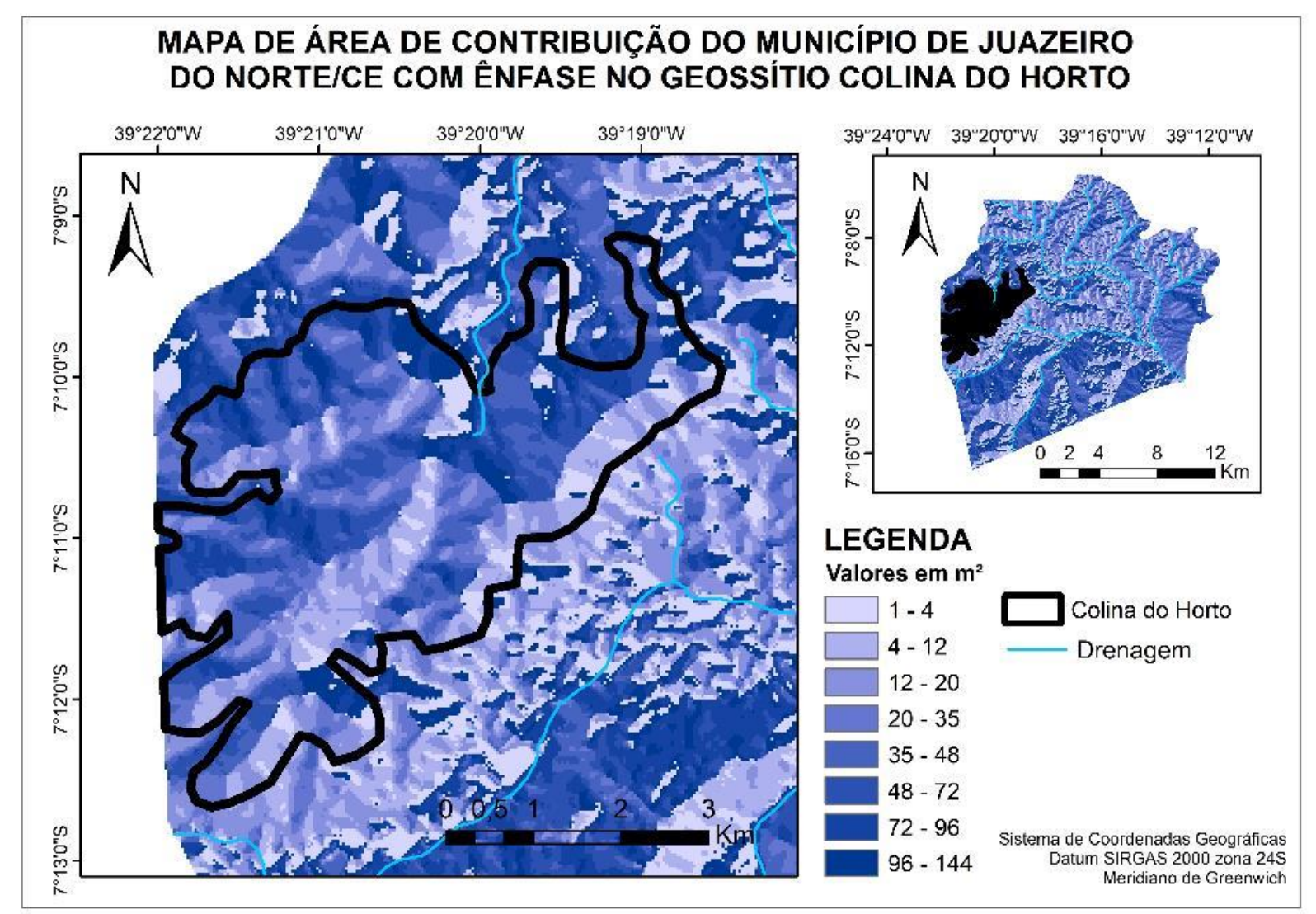

Figura 3 - Mapa de Área de contribuição $\left(\mathbf{m}^{2}\right)$.

Conforme o mapa geomorfológico (Figura 4), a unidade da Colina é um relevo residual cujo material litológico é composto por rochas cristalinas do Pré-cambriano datadas em cerca de 650 milhões de anos. São Granitos e Dioritos, além de rochas metamórficas como Filitos, que se comportam de maneira diferenciada diante da ação dos processos denudacionais (MOCHIUTTI et al., 2012). Fatores como a declividade, que ocorre em torno de $45 \%$ a $75 \%$, tornam a área um ambiente onde predominam os processos morfogenéticos como a dissecação de suas vertentes. Além disso, a tipologia do substrato geológico faz com que haja uma resistência ao intemperismo e ocorra a erosão diferencial. Essa elevação é resultado tanto do soerguimento regional, quanto de processos de erosão, de modelação e de degradação por fatores exógenos (LIMA et al., 2012).

Estudos Geográficos, Rio Claro, 16(2): $\quad 193-212, \quad$ jul./dez. $2018 \quad$ (ISSN $\quad$ 1678-698X) http://www.periodicos.rc.biblioteca.unesp.br/index.php/estgeo 


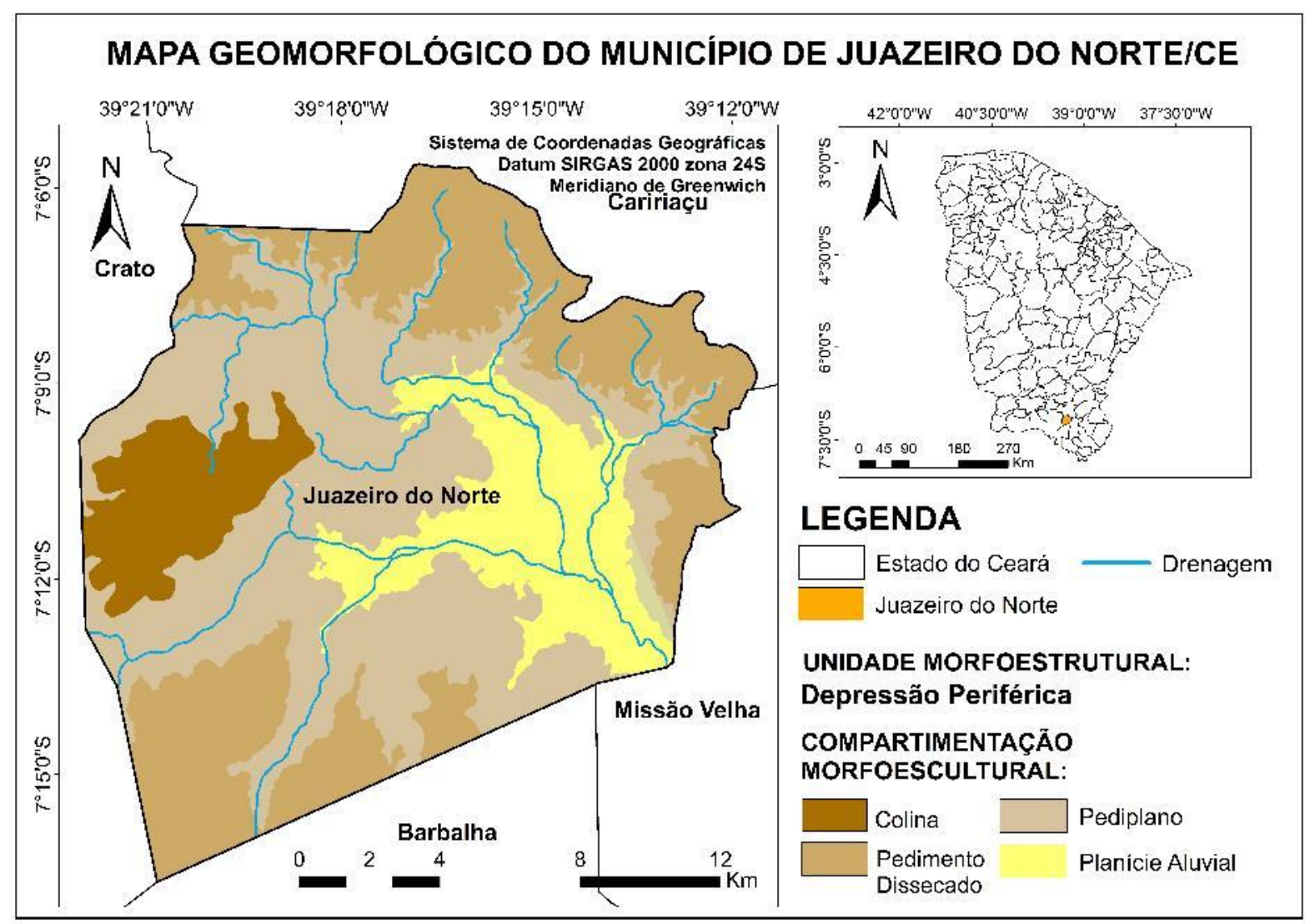

Figura 4 - Mapa geomorfológico do município de Juazeiro do Norte/CE.

Do ponto de vista morfodinâmico, a superfície de cimeira da Colina, área onde se concentra maior parte da ocupação urbana, pode ser considerada estável em relação a sua encosta, onde o manto de intemperismo é incipiente, nos quais grandes blocos rochosos encontram-se expostos a ação do clima e da declividade, favorecendo a ocorrência de movimentos gravitacionais de massa. No setor mais rebaixado da encosta, adentrando a unidade do Pediplano, devido a diminuição da declividade, os processos pedogenéticos atuam de maneira mais notável, em relação aos morfogenéticos, tornando a área um ambiente agricultável (Figura 5).

Estudos Geográficos, Rio Claro, 16(2): 193-212, jul./dez. $2018 \quad$ (ISSN 1678-698X) http://www.periodicos.rc.biblioteca.unesp.br/index.php/estgeo 


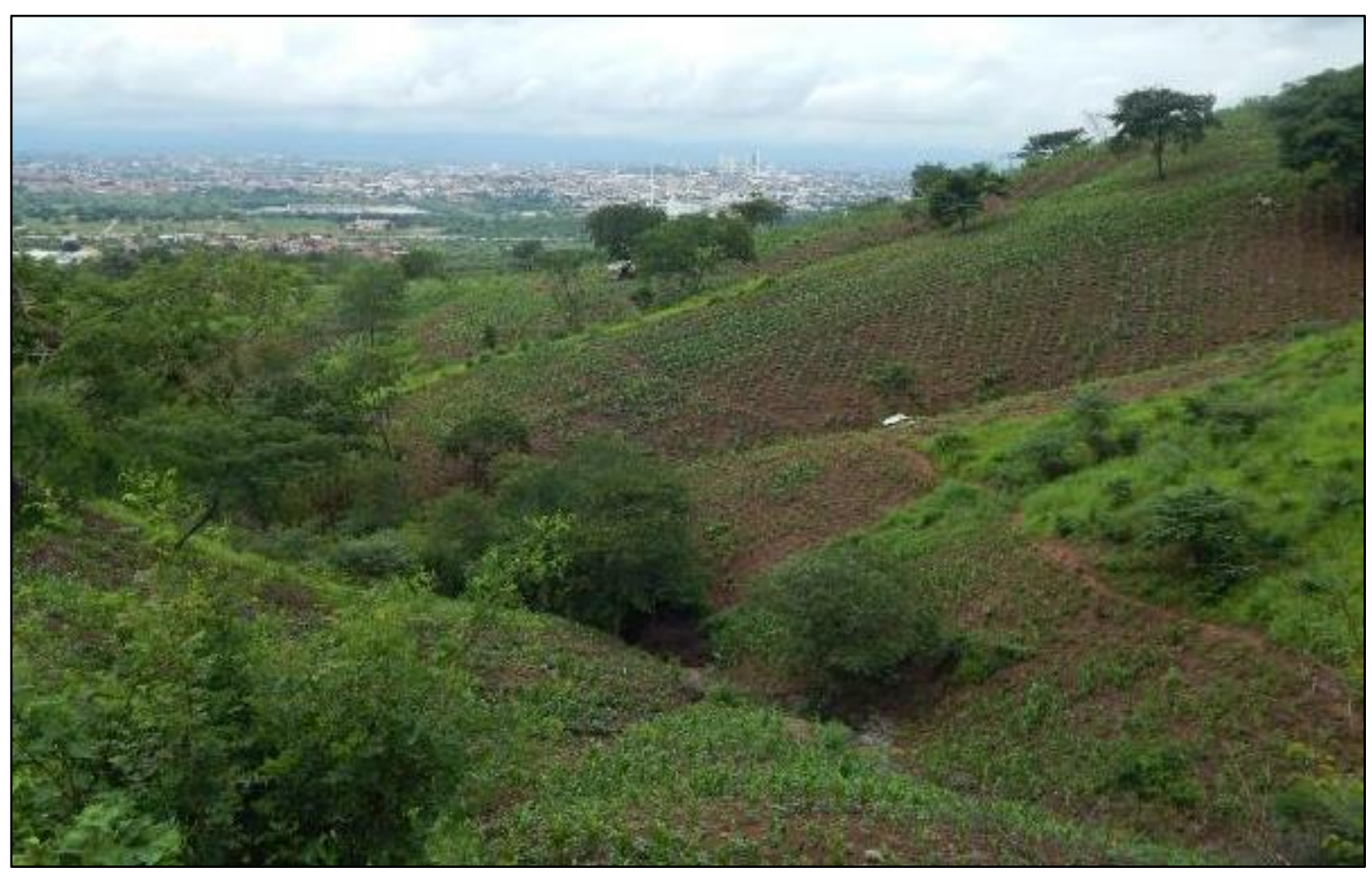

\section{Figura 5 - Cultivos na encosta da Colina do Horto.}

De acordo com Ribeiro et al. (2010, p. 130) "Pediplano é o nome dado a uma região aplainada em clima árido ou semiárido caracterizada por se originar da coalescência de pedimentos, litossolos e/ou extensos afloramentos". Portanto, o território de Juazeiro do Norte se apresenta como um pediplano com altitudes médias de $400 \mathrm{~m}$ (Figura 6). Este é formado por pedimentos que refletem a modelagem sendo esculpida pela dissecação, tendo como resultado o recuo de suas vertentes, sendo seu principal agente modelador, a drenagem.

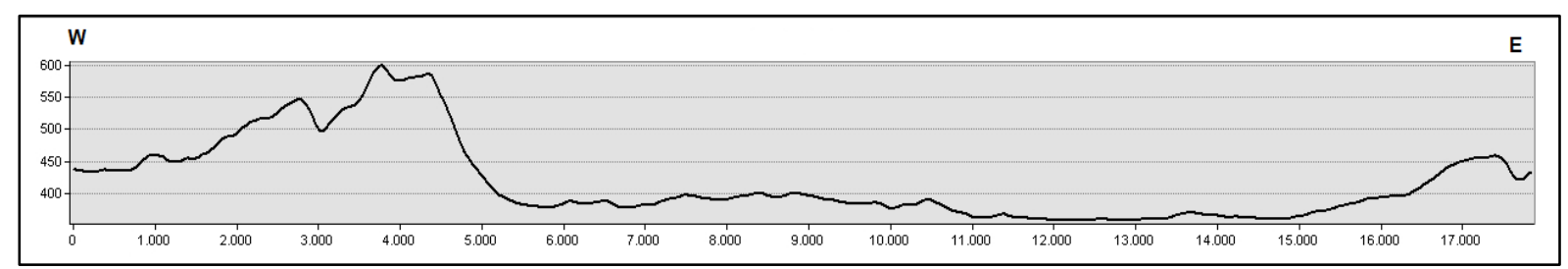

Figura 6 - Perfil topográfico do município de Juazeiro do Norte/CE.

$\mathrm{Na}$ área de Planície Aluvial o processo de agradação prevalece a partir da acomodação de sedimentos como parte da dinâmica fluvial dos canais presentes. As principais redes de drenagem que cortam o município são o rio Salgadinho e o riacho das Timbaúbas, ambos pertencentes a sub-bacia hidrográfica do rio Salgado. A origem desses canais está nas cabeceiras de drenagem da Colina do Horto e nas concavidades dos pedimentos.

Estudos Geográficos, Rio Claro, 16(2): $\quad 193-212, \quad$ jul./dez. $2018 \quad$ (ISSN $\quad$ 1678-698X) http://www.periodicos.rc.biblioteca.unesp.br/index.php/estgeo 


\section{MODELO SHALSTAB E QUEDA DE BLOCOS}

É possível observar, de acordo com os resultados do SHALSTAB, que a maior parte do município foi classificada como uma área incondicionalmente estável para a ocorrência de escorregamentos translacionais rasos (Figura 7), com exceção apenas da Colina do Horto. Embora as condições altimétricas e declivosas tornem essa área um ambiente morfodinamicamente mais instável, a classificação de suscetibilidade a escorregamentos para o maciço é baixa, estando localizada nas classes intermediárias de -3,1 a 9,9 (baixa a média suscetibilidade).

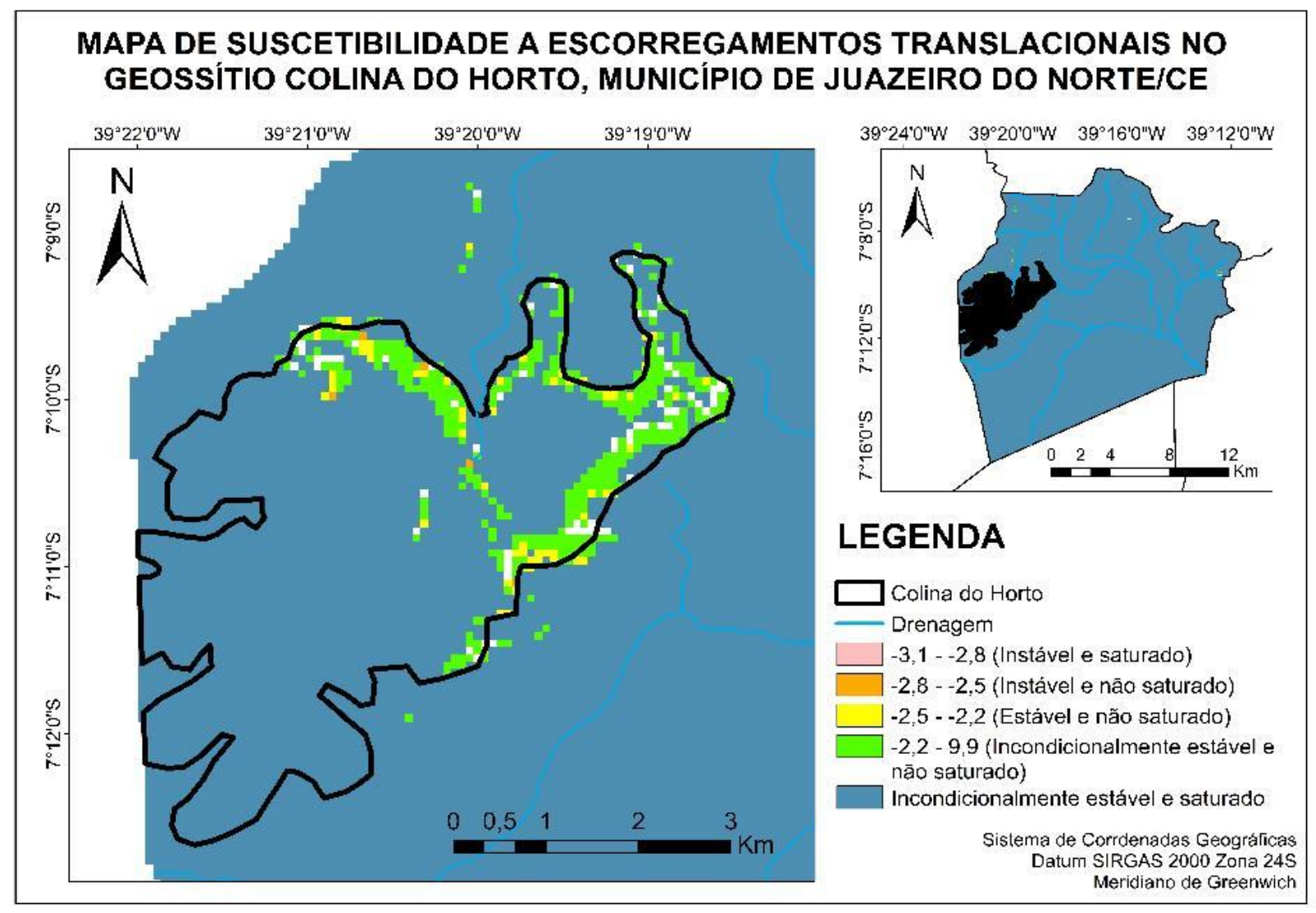

Figura 7 - Mapa de suscetibilidade a escorregamentos com ênfase no Geossítio Colina do Horto. Parâmetros utilizados: $\mathrm{Cs}-0 \mathrm{~N} / \mathrm{m}^{2} ; \mathrm{Cr}-0 \mathrm{~N} / \mathrm{m}^{2} ; 1.600 \mathrm{Kg} / \mathrm{m}^{3} ; \mathrm{f}-35^{\circ}$ graus; $\mathrm{W}-0 / \mathrm{m}^{2}$; $\mathrm{Z}-3$ metros.

Esse fato decorre, sobretudo, pelo manto de intemperismo pouco espesso e em algumas áreas inexistente e, ao grupo de litotipos da área, composto por associações de granitos, granodioritos, monzonito, sienito e leucogranito (CPRM, 2003), que atrelados ao fator declividade, dificultam a ação do intemperismo e, consequentemente, a formação de solos desenvolvidos.

Dessa forma, com a aplicação do modelo SHALSTAB não foi possível identificar áreas com alto grau de suscetibilidade a escorregamentos, porém, por meio de atividades em campo foi constatado a presença de blocos rochosos dispostos ao longo da encosta do maciço e cicatrizes que apontam os pontos de ruptura desses blocos e lascas rochosas. Esse fato denota a ação de processos exógenos que ocasionaram o desprendimento, o deslocamento e a deposição desse material.

Estudos Geográficos, Rio Claro, 16(2): 193-212, jul./dez. $2018 \quad$ (ISSN 1678-698X) http://www.periodicos.rc.biblioteca.unesp.br/index.php/estgeo 
$\mathrm{Na}$ área, fatores como a precipitação média anual alta e a declividade acentuada, somadas as interferências antrópicas, configuram um cenário de risco para a população residente no âmbito da Colina quanto a ocorrência de quedas de blocos (Figura 8 e Figura 9).

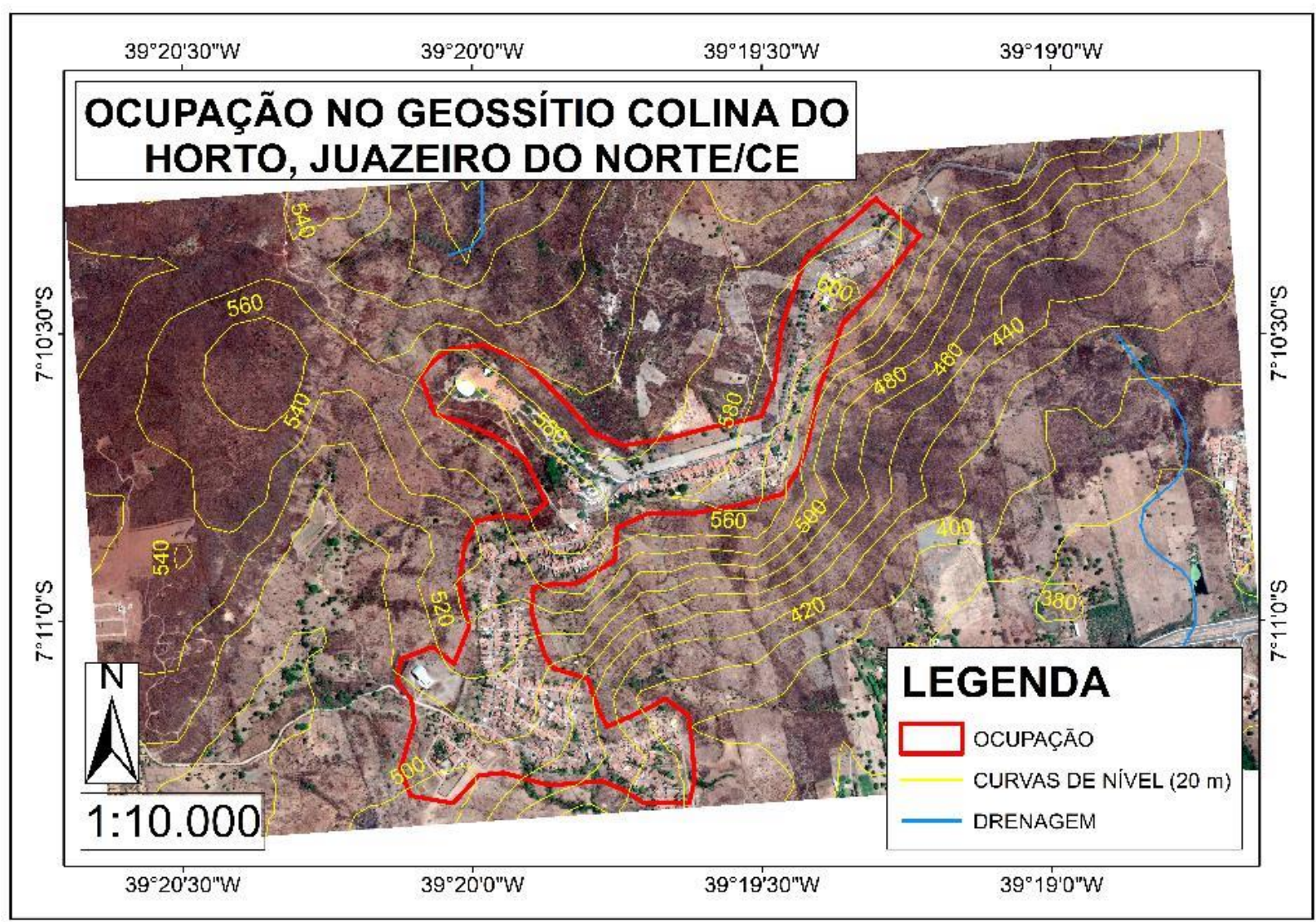

Figura 8 - Ocupação no Geossítio Colina do Horto.

Devido ao forte atrativo turístico, por ser essa uma área que desperta interesse científico, do ponto de vista cênico, físico, histórico e religioso, e também pelas atividades de cunho religioso que movimentam a economia local, a ocupação da Colina é composta majoritariamente por prédios residenciais dos chamados Romeiros, comerciais e vias de acesso que estão dispostos em setores da encosta e no topo da Colina (Figura 9).

Estudos Geográficos, Rio Claro, 16(2): $\quad 193-212, \quad$ jul./dez. $2018 \quad$ (ISSN $\quad$ 1678-698X) http://www.periodicos.rc.biblioteca.unesp.br/index.php/estgeo 


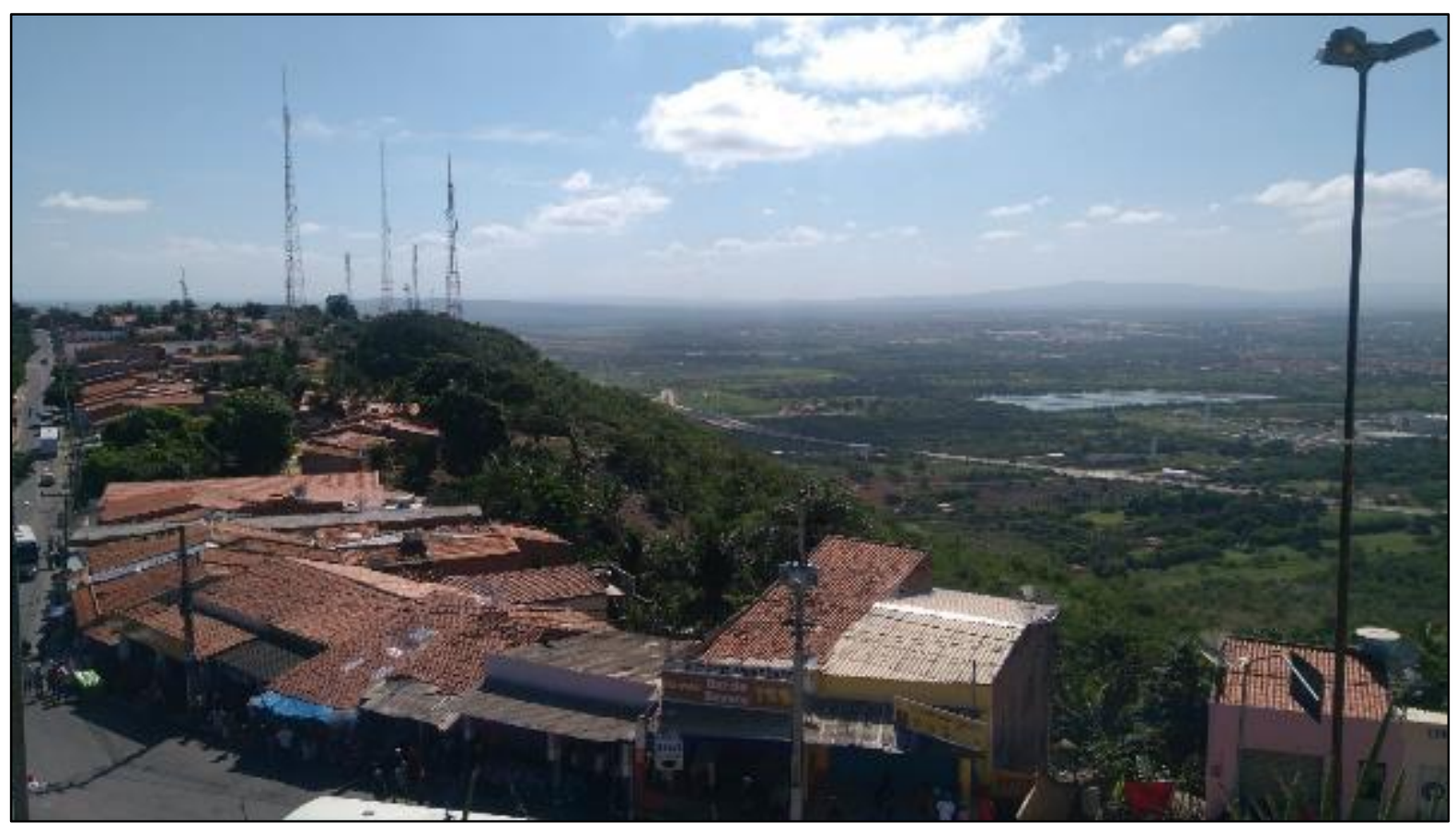

Figura 9 - Ocupação urbana no maciço.

Além dos fatores naturais, a possibilidade de risco se concretiza devido a densa ocupação em setores da encosta, e pelos eventos religiosos que movimentam um grande contingente de pessoas durante todo o ano, o que torna a população vulnerável. Tais atividades exercem pressão sobre o maciço, que há muito vem sofrendo com a fragmentação e o desprendimento de blocos rochosos.

As áreas de encosta da colina são marcadas pela presença de depósitos de matacões, configurando-se como blocos rochosos de granulação variada. A presença desses blocos associada a declividade das encostas gera um input para o deslocamento da rocha, favorecendo a sua queda. Gerscovich (2012) afirma que a instabilidade das encostas faz parte da sua própria dinâmica evolutiva, pois os processos intempéricos e erosivos influenciam no destaque dos materiais (solo, rocha) que serão transportados pela ação da gravidade.

No ambiente da Colina do Horto foi possível identificar duas modalidades de movimentos de bloco, por queda e por desplacamento. As quedas de blocos correspondem ao movimento de blocos rochosos ao longo de superfícies inclinadas. Quando o bloco se encontra parcialmente imerso na matriz terrosa, o fator desencadeante é a perda de apoio, que pode ser ocasionada pela atuação de processos erosivos. Quando o bloco se encontra preso na matriz rochosa, os processos intempéricos passam a atuar nos seus pontos de fraqueza ocasionando o seu desprendimento (Figura 10).

Estudos Geográficos, Rio Claro, 16(2): 193-212, $\quad$ jul./dez. $2018 \quad$ (ISSN $\quad$ 1678-698X) http://www.periodicos.rc.biblioteca.unesp.br/index.php/estgeo 


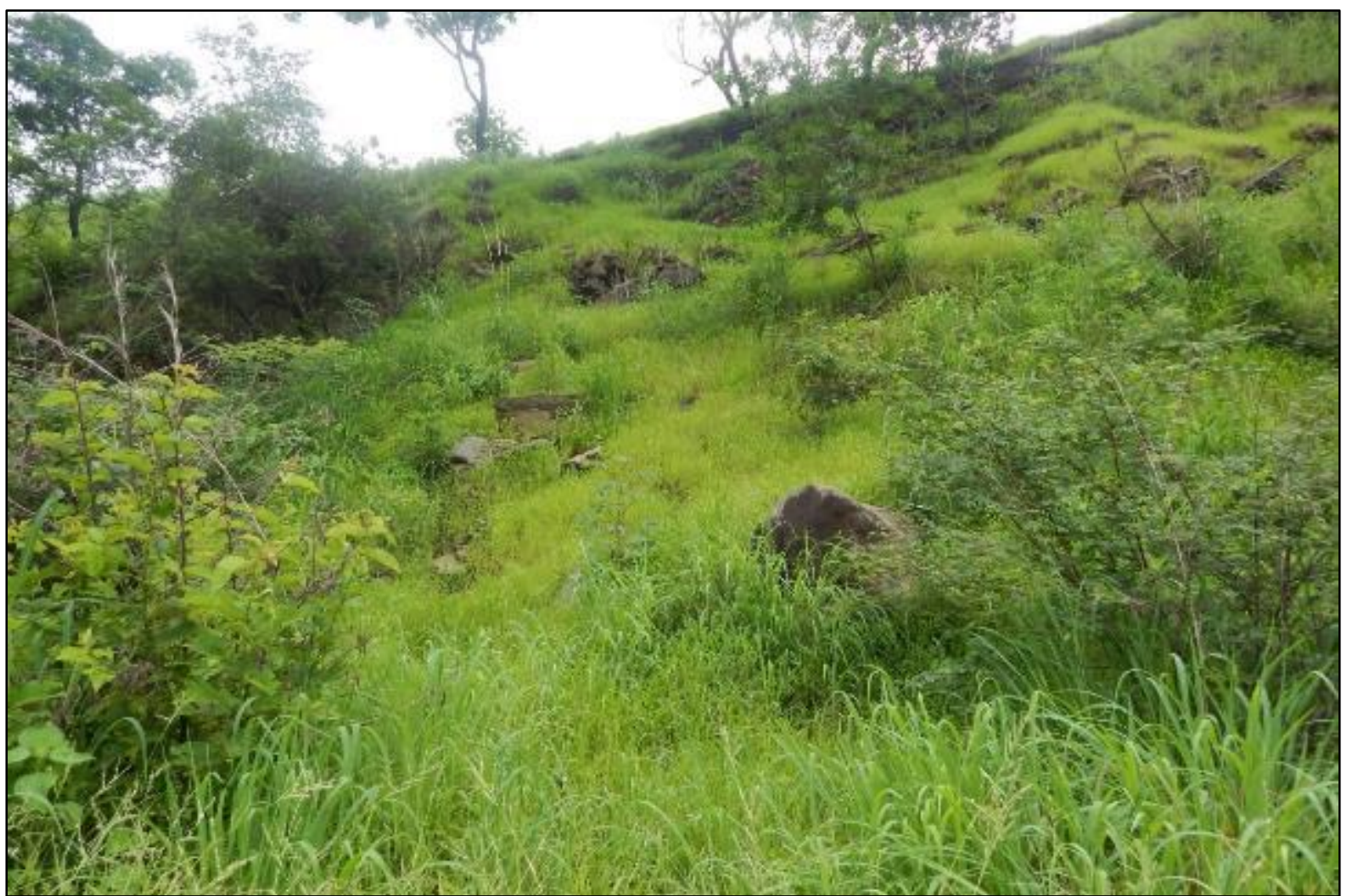

Figura 10 - Matacões dispostos na encosta da Colina do Horto.

Muitos cortes no talude rochoso do maciço foram executados para a construção de vias de acesso e de moradias, no qual o impacto desses cortes atinge as zonas de fraqueza da rocha facilitando o seu fraturamento. A partir das fraturas a percolação da água e a variação térmica diária (termoclastia) atua com maior efetividade na desagregação dos minerais, resultando na quebra da rocha (BRICALLI et al., 2001). Com o rompimento, o movimento gravitacional é deflagrado.

Em linhas gerais, trata-se de materiais rochosos de volume e de litologia diferenciadas, que se destacam de taludes ou encostas íngremes e deslocam por dois tipos de movimentos: por rolamento, quando a encosta possui inclinação menor que 90 graus, permitindo que o bloco se desloque sobre a sua superfície até encontrar um ponto de apoio; e por queda livre, quando a encosta possui um ângulo de inclinação abrupto igual ou superior a 90 graus (SILVEIRA, 2017).

$\mathrm{Em}$ todas as áreas em que a presença de blocos desprendidos e cicatrizes foram constatadas, a interferência antrópica era um dos elementos que se faziam presentes durante a análise dos possíveis fatores desencadeantes do processo. $O$ trajeto percorrido em campo corresponde a uma área extensa onde foram realizados cortes para construção de estrada, e como já mencionado, esse fato contribuiu para acionar as zonas de fraqueza e planos de fratura dos taludes atingidos.

Como parte da dinâmica natural de todo material que esteja exposto a ação dos agentes externos modeladores da paisagem, em todos os pontos visitados em campo foi possível perceber claramente as atividades intempéricas nas suas modalidades física, química e biológica atuando sobre o maciço. No entanto, é preciso destacar o papel das raízes no processo de fragmentação da rocha, pois estas se aproveitam das fraturas existentes para se fixar, ou mesmo ajudam a produzi-las por meio da tensão que provocam.

Estudos Geográficos, Rio Claro, 16(2): $\quad 193-212, \quad$ jul./dez. $2018 \quad$ (ISSN $\quad$ 1678-698X) http://www.periodicos.rc.biblioteca.unesp.br/index.php/estgeo 
Devido à quebra de declividade e, também, da dimensão dos blocos, não permitindo que os mesmos fossem transportados pelas águas das chuvas, em alguns locais o material destacado está disposto junto ao talude, sendo possível perceber o seu ponto de ruptura (Figura 11).

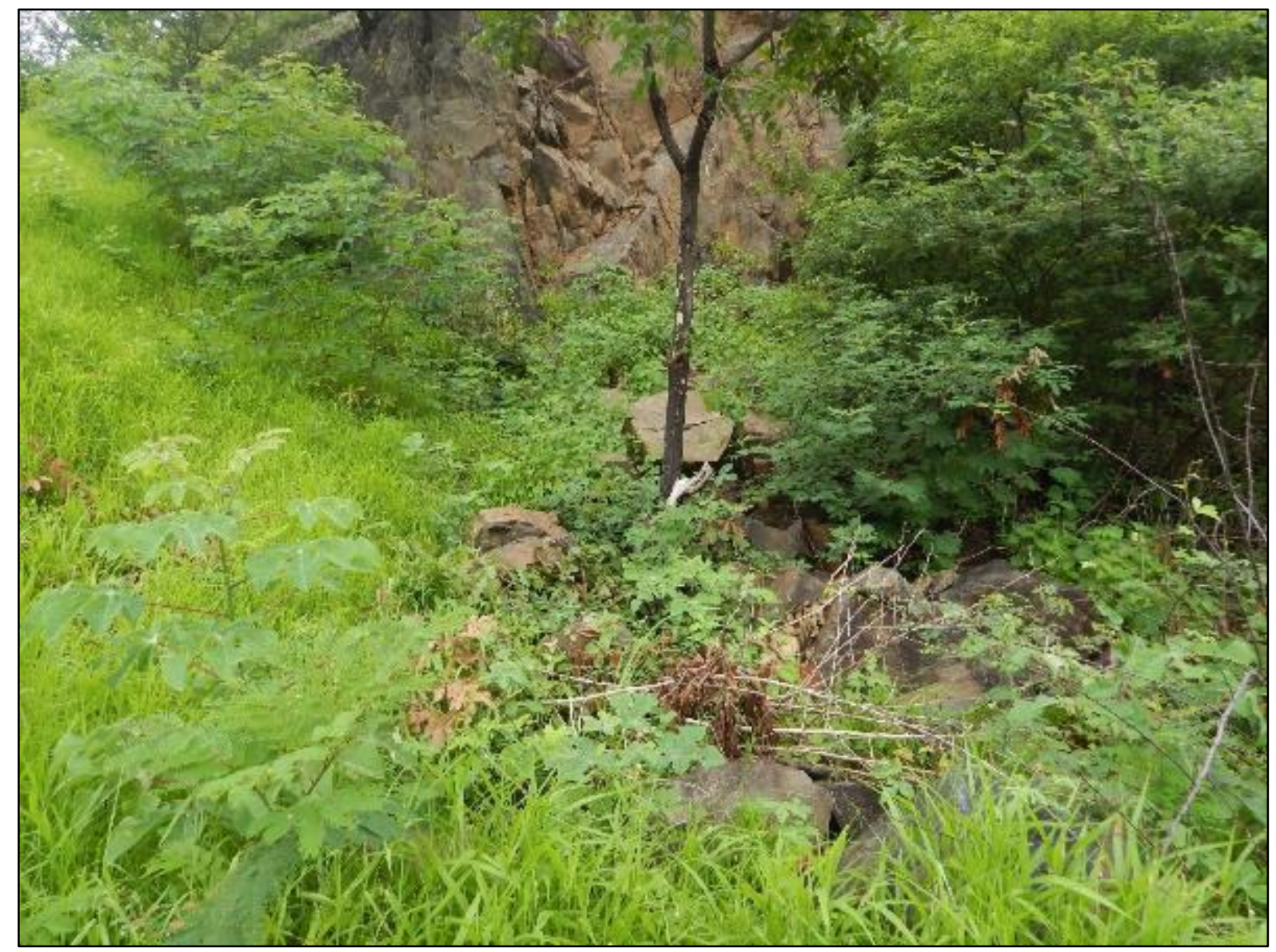

Figura 11 - Matacões que se destacaram do talude.

Apesar de toda a área possuir características similares quanto aos processos antrópicos, climáticos, topográficos (ex. declividade), intempéricos e erosivos, alguns setores estão mais fraturados e, portanto, mais propícios a sofrerem com o desprendimento dos blocos. Pode-se atribuir esse fato aos diferentes graus de dureza da rocha, ou seja, a sua resistência aos processos de alteração e fragmentação, e ao material litológico, composto basicamente por rochas ígneas intrusivas de composição e arranjo mineralógico diferenciados (CPRM, 2003).

Nesse sentido, o desplacamento consiste no processo onde lascas ou placas de rocha que se formam a partir de estruturas (xistosidade, acamamento), movimentam-se devido a variações térmicas ou por alívio de tensão (PINOTTI; CARNEIRO, 2013). O desprendimento pode se dar por queda livre ou por escorregamento. O intemperismo físico, predominante no semiárido nordestino, e biológico (a partir da força exercida pelas raízes), são os principais fatores desencadeantes do desprendimento desses fragmentos, pois o efeito da biota e da variação térmica contribui para a abertura de fraturas (Figura 12), que posteriormente, contribuirão para o desprendimento de blocos do pacote rochoso.

Estudos Geográficos, Rio Claro, 16(2): 193-212, jul./dez. $2018 \quad$ (ISSN 1678-698X) http://www.periodicos.rc.biblioteca.unesp.br/index.php/estgeo 


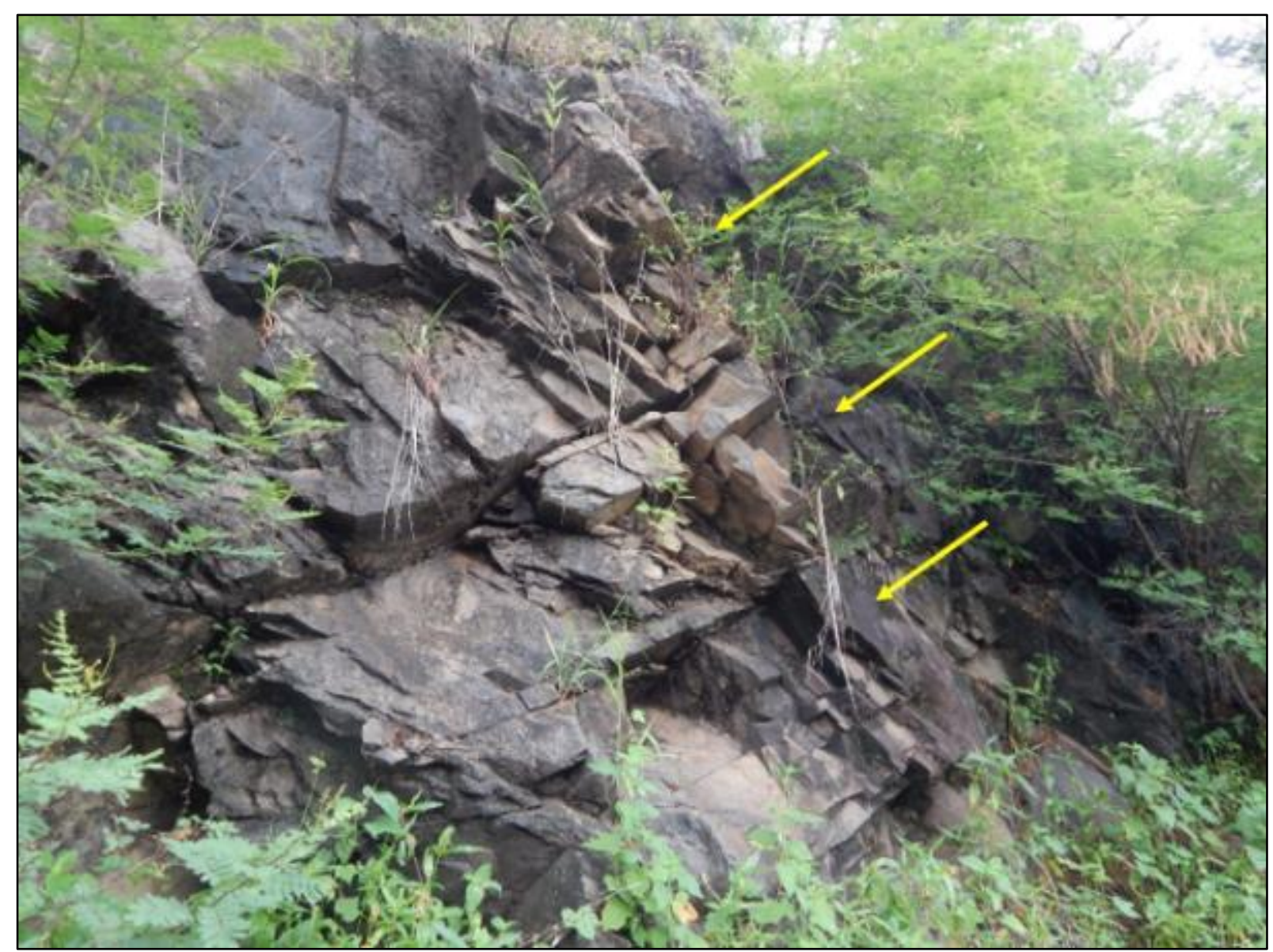

Figura 12 - Cicatrizes decorrentes do desplacamento de lascas de rocha.

O talude em questão encontra-se intensamente fraturado e fragmentado denotando o seu plano de clivagem em linhas paralelas, configurando-se como um fator determinante na ocorrência desse tipo específico de movimento de massa, que será agravado pelo intemperismo e pela interferência antrópica. Devido à dimensão das placas que se desprenderam do talude, não foi encontrado nas suas proximidades a área de repouso desse material que possivelmente foi transportado pela água.

\section{CONSIDERAÇÕES FINAIS}

Do ponto de vista geomorfológico, o município de Juazeiro do Norte possui formas, majoritariamente, planas e suave onduladas, sendo caracterizadas por áreas que possuem baixos graus de declividade, com exceção do Geossítio Colina do Horto. Em linhas gerais, a partir do mapeamento e das visitas in loco, foi constatado que as quedas de blocos são o tipo de movimento de massa de maior suscetibilidade a ocorrência nos setores de encosta do Geossítio, tendo como fatores desencadeantes, a declividade e o fraturamento do pacote rochoso, ocasionado pelos processos intempéricos e pelos cortes no talude.

O presente estudo oferece uma relevante colaboração ao conhecimento dos processos exógenos no Geossítio Colina do Horto, demonstrando também o seu potencial como subsídio aos trabalhos de monitoramento aos possíveis desastres naturais na área. Da mesma forma, procura auxiliar nos planos de gestão ambiental

Estudos Geográficos, Rio Claro, 16(2): $\quad 193-212, \quad$ jul./dez. $2018 \quad$ (ISSN 1678 -698X) http://www.periodicos.rc.biblioteca.unesp.br/index.php/estgeo 
pelos órgãos responsáveis, e, pela própria comunidade residente, tendo em vista o planejamento e o controle do uso e ocupação da terra no Geossítio.

Quanto ao SHALSTAB, trata-se de um modelo eficiente na previsão de áreas susceptíveis a escorregamentos translacionais rasos. A sua aplicação no município de Juazeiro do Norte foi válida, pois demonstrou que mesmo em áreas com declividade acentuada como no Geossítio Colina do Horto, não foi constatado a suscetibilidade a escorregamentos, além de suas primeiras aplicações do modelo para o semiárido nordestino.

\section{REFERÊNCIAS}

ALVES, C. C. E. et. al. Geopark Araripe: Um Estudo Geoturístico e Ambiental no Geotope Granito, Ceará/Brasil. VI Seminário Latino Americano de Geografia Física II Seminário Ibero Americano de Geografia Física Universidade de Coimbra, 2010.

ASSINE, M.L. Sedimentação e Tectônica da Bacia do Araripe, Nordeste do Brasil. Dissertação de Mestrado, IGCE/ UNESP, Rio Claro, 1990. 124 p.

Bacia do Araripe. Boletim de Geociências. Petrobras, Rio de Janeiro, v. 15, n. 2, p. 371-389, maio/nov. 2007.

BASTOS, F. H.; PEULVAST, J. Suscetibilidade a ocorrência de movimentos de massa no Maciço de Baturité-Ceará, Brasil. Revista do Departamento de Geografia USP, v. 32, 2016.

BORBA, A. W. de. Geossítios pontuais essenciais ao ensino de Geociências no Rio Grande do Sul: características e importância para a Geoconservação. Geonomos, 21(2),72-78, 2013

BRICALLI, L. L.; SCABELO, M. Queda de blocos e ocupações irregulares na sede do município de Mimoso do Sul (ES-Brasil). In: 8 Encontro de Geógrafos de América latina. Santiago de Chile: Media Graphics, 2001, p. 55-64.

CARVALHO-NETA, M. L.; CORRÊA, A. C. B.; SILVA, D. G. Esboço geomorfológico do Geopark Araripe/CE como ferramenta para a geoconservação. Anais do XII Simpósio Nacional de Geomorfologia. Maringá - PR, 2016.

CORRÊA, A. C. B. et al. Megageomorfologia e morfoestrutura do Planalto da Borborema. Revista do Instituto Geológico, São Paulo, 31 (1/2), 35-52, 2010.

CPRM. Atlas digital de geologia e recursos minerais do Ceará. Mapa na escala de 1:500.000. Fortaleza: Serviço Geológico do Brasil/Ministério das Minas e Energia, 2003.

FERNANDES, N. F. et al. Condicionantes geomorfológicos dos deslizamentos nas encostas: avaliação de metodologias e aplicação de modelo de previsão de áreas susceptíveis. Revista Brasileira de Geomorfologia, v. 2, p. 51-71, 2001.

Estudos Geográficos, Rio $\quad$ Claro, $\quad$ 16(2): $\quad 193-212, \quad$ jul./dez. $2018 \quad$ (ISSN 1678 -698X) http://www.periodicos.rc.biblioteca.unesp.br/index.php/estgeo 
FERREIRA, A. G.; MELLO, N. G. S. Principais sistemas atmosféricos atuantes sobre a Região Nordeste do Brasil e a influência dos oceanos pacífico e atlântico no clima da região. Revista Brasileira de Climatologia, v.1, n. 1, 2005.

FUNCEME. Levantamento de Reconhecimento de Média Intensidade de Solos Mesorregião do Sul Cearense. Fundação Cearense de meteorologia e Recursos Hídricos, Fortaleza: 2012. 280 p.

FUNCEME. Zoneamento geoambiental do estado do Ceará: parte II Mesorregião do Sul Cearense. Fortaleza: 2006.

GEOPARK ARARIPE. Disponível em: <www.geoparkararipe.org.br>. Acesso em: 15 de março de 2018.

GERSCOVICH, D. Estabilidade de taludes. São Paulo: Oficina de Textos, 2012.

GUERRA, A. J. T. Encostas Urbanas. In: Geomorfologia Urbana. Antônio José Teixeira Guerra (org.). Rio de Janeiro: Bertrand Brasil, 2011.

IBGE. Manual técnico de geomorfologia. $2^{a}$ ed. Rio de Janeiro: IBGE, 2009.

IPECE (Instituto de Pesquisa e Estratégia Econômica do Ceará). Juazeiro do norte: perfil básico do município. Fortaleza/CE. 2017. Disponível em: $<$ www.ipece.ce.gov.br $>$. Acesso em 30 de janeiro de 2018.

LIMA, F. J. Evolução geomorfológica e reconstrução paleoambiental do setor subúmido do Planalto Sedimentar do Araripe: um estudo a partir dos depósitos coluviais localizados nos municípios de Crato e Barbalha - Ceará. Tese (Doutorado em Geografia). Universidade Federal de Pernambuco. Recife, 2015.

LIMA, G. G.; RIBEIRO, S. C. Geomorfologia e Paisagem do município de Juazeiro do Norte/CE: relações entre a natureza semiárida e os impactos antrópicos. Revista Geonorte, Edição Especial, V.2, N.4, p.520 - 530, 2012.

LISTO, F. L. R.. Modelos matemáticos aplicados à previsão de escorregamentos translacionais rasos: exemplos em áreas naturais e de risco. Clio. Série Arqueológica (UFPE), v. 31, p. 91, 2016.

MELO, C. E.; BANDEIRA, A. P. N. Estudo do colapso dos solos para dimensionamento de fundações superficiais. XVII Congresso Brasileiro de Mecânica dos solos e engenharia geotécnica. Goiânia -GO, 2014.

MOCHIUTTI, N. F. et al. I. Os Valores da Geodiversidade: Geossítios do Geopark Araripe/CE. Anuário do Instituto de Geociências - UFRJ. Rio de Janeiro, 2012.

MONTGOMERY, D.R.; DIETRICH, W.E. (1994). A physically-based model for the topographic control on shallow landsliding. Water Resources Research (30). p. 1153-1171, 1994.

Estudos Geográficos, Rio Claro, 16(2): $\quad 193-212, \quad$ jul./dez. $2018 \quad$ (ISSN $\quad$ 1678-698X) http://www.periodicos.rc.biblioteca.unesp.br/index.php/estgeo 
PINOTTI, A. M.; CARNEIRO, C. D. R. Geologia Estrutural na previsão e contenção de queda de blocos em encostas: aplicação no Granito Santos, SP. TERRA E DIDATICA 9-2:132-168, 2013.

OLIVEIRA, P. C. A.; RODRIGUES. S. C.; Cartografia do relevo: um estudo aplicado na região oeste de minas gerais. Revista Brasileira de Geomorfologia - Ano 8, no 2, 2007.

RIBEIRO, S. C. et al. Geomorfologia de áreas semi-áridas: uma contribuição ao estudo dos sertões nordestinos. Revista de Geografia. Recife: UFPE - DCG/NAPA, v. 27, n. 1,2010 .

SBROGLIA, R. M. et al. Mapeamento de Áreas Suscetíveis a Deslizamentos Translacionais com o Uso da Ferramenta ASA - Automatic Shalstab Analysis. XII Conferencia Brasileira sobre Estabilidade de Encostas, COBRAE 2017, Florianópolis/SC, Brasil.

SILVA, F. M. A. et al. Análise das precipitações pluviométricas na sub-bacia do rio salgado, sul cearense (1979 - 2008). In: Simpósio Nacional de Climatologia Geográfica, 9, 2010, Fortaleza. Anais... Fortaleza: UFC, 2010. 1 CD.

SILVEIRA, L. R. C. Avaliação do perigo de queda de blocos em taludes urbanos e ferroviários e simulação de sua trajetória. Dissertação. Universidade Federal de Ouro Preto - UFOP. Ouro Preto, 2017.

Artigo submetido em: 11/06/2018 Aceito para publicação em: 14/11/2018 Publicado em: 14/12/2018 